\title{
Kedudukan Anak Yang Lahir Di Luar Pernikahan Di Tinjau Dari Kompilasi Hukum Islam
}

\author{
Tri Khartika Nurry Wiranty, Emmi Rahmiwita Nasution, Irda Pratiwi
}

\author{
Fakultas Hukum Universitas Asahan \\ JL. Jend. Ahmad Yani, Kisaran Naga, Asahan, Sumatera Utara
}

Telp: (0623) 42643, Kode Pos 21216

Email: nurrywuranty@gmail.com (CA)

\begin{abstract}
Naskah Diterima: II-10-2019, Direvisi: DI-07-2020, Disetujui: 06--77-2020, Diterbitkan: 07-07-2020 DDI: https://dai.arg//0.30596/dll.v5iZ.3576
\end{abstract}

\begin{abstract}
Abstrak
Kompilasi Hukum Islam Pasal 99 menyatakan anak yang sah adalah anak yang Lashir dalam atau sebagai akibat perkawinan yang sah dan hasil pembuahan suami istri yang sah di luar rahim dan di lahirkan oleh istri tersebut yang artinya bahwa anak dikatakan sah apabila lahir dari perkawinan yang resmi. Bila dikatakan anak yang lahir akibat perkawinan yang sah tidak ada masalah, namun anak yang lahir dalam masa perkawinan yang sah ini akam menimbulkan suatu kecurigaan apabila pasal ini di hubungkan dengan pasal lain yang membolehkan wanita hamil karena zina menikah dengan laki-laki yang menghamilinya. Perkawinan perempuan hamil karena zina dengan pria yang menghamilinya adalah perkawinan yang sah. Dalam penulisan ini penulis menggunakan metode penelitian yuridis normatif yang melakukan pendekatan secara undang-undang. Dalam penulisan ini juga mengangkat dua permasalahn hukum yang adalah bagaimana akibat hukum anak yang di lahirkan wanita hamil yang dinikahkan menurut Kompilasi Hukum Islam dan bagaimana kedudukan anak luar nikah ditinjau berdasarkan Kompilasi Hukum Islam (KHI). Berdasarkan dari penulisan ini dapat di simpulkan bahwa anak yang lahir di luar pernikahan hanya memiliki hubungan nasab dengan ibunya dan keluarga ibunya.
\end{abstract}

\section{Kata Kunci: Peraturan Hukum, Kedudukan Anak, Perkawinan Yang Sah.}

\begin{abstract}
Article 99 in Compilation of Islamic Law which states that: a legitimate child is a child born in or as a result of a legal marriage and the result of fertilization of a legal husband and wife outside the womb and born by the wife, which means that the child is said to be legitimate when born from marriage official one. If it is said "children born as a result of a legal marriage there are no problems, but children born during this legal marriage will raise suspicion if this Article is linked to other Articles that allow pregnant women because adultery marries a man who impregnates". a marriage of a pregnant woman because of adultery with a man who impregnates her is a legal marriage. In this paper the author uses normative juridical research methods that approach the law. In this paper also raised two legal issues that are how the legal consequences of children born to pregnant women married according to the Compilation of Islamic Law and how the position of out of wedlock children is reviewed based on a compilation of Islamic Law. Based on this writing, it can be concluded that a child born outside of marriage only has a nasab relationship with his mother and his mother's family.
\end{abstract}

Keywords: Legal Regulations, Position of Children, Legitimate Marriage. 


\section{PENDAHULUAN}

Perkawinan adalah suatu peristiwa penting di dalam kehidupan manusia karena perkawinan tidak saja menyangkut pribadi kedua calon suami istri yaitu laki-laki dan perempuan, tapi juga menyangkut masalah keluarga dan masalah orang di sekitar lingkungan. Setiap perkawinan selalu dianggap sebagai suatu yang sakral serta suci karena setiap kepercayaan selalu menghubungkan kaidah perkawinan dan kaidah agama islam yang di jelaskan dalam (Q.S. An-Nissa: 3) yang Artinya: Maka nikahilah wanita-wanita yang kamu senangi dua tiga atau empat, kemudian jika kamu takut tidak akan dapat berlaku adil, maka nikahilah seorang saja.

Menurut Kompilasi Hukum Islam didalam Pasal 2 menyatakan bahwa perkawinan menurut hukum islam adalah pernikahan, yaitu akad yang sangat kuat atau mitsaqan ghalidzan untuk menaati perintah Allah dan melaksanakannya merupakan ibadah. (Lihat Pasal 2 Kompilasi Hukum Islam) Sedangkan tujuan perkawinan terletak di dalam Pasal 3 Kompilasi Hukum Islam yang menyatakan bahwa perkawinan bertujuan untuk mewujudkan kehidupan rumah tangga yang sakinah, mawaddah, dan rahma. Demikian juga dalam pasal 4 disebut perkawinan adalah sah apabila dilakukan dalam hukum islam sesuai dengan pasal 2 ayat 1 undang-undang nomor 1 tahun 1974 (Lihat Kompilasi Hukum Islam, h. 14-15 ).

Pada masa saat ini merupakan zaman dimana mana perbuatan tercela dan hina sering terjadi. Tidak menutup kemungkinan bahwa semua kalangan tidak melakukan hal tersebut dimana kita ketahui bahwa banyak remaja melakukan perbuatan maksiat yang tidak terkendali dan tidak di awasi oleh keluarganya dan hal ini juga merupakan pengaruh dari lingkungan yang tidak baik. Masa puber remaja mengakibatkan tidak terkendali emosi yang menjerumuskan si remaja berbuat kemaksiatan (Santoso, 2017, h. 2).

Lembaga perkawinan selalu menghadapi tantangan yang berkaitan dengan masalah sosial di masyarakat yang bisa terancam eksistensinya ketika dihadapkan pada problem sosial yang mencoba mengusik kesakralan institusinya. Salah satu masalah sosial tersebut adalah banyaknya kasus yang menimpah wanita terhadap masalah hamil diluar nikah. Masalah ini tidak hanya mengenai kehamilan saja akan tetapi ini menyangkut tentang para pelaku yang melakukan perbuatan tersebut dan mengenai status hukum anak di dalam kandunganya (Quthb, 1987, h. 24).

Di Indonesia pengaturan masalah perkawinan yang terdapat dalam Pasal 53 Kompilasi Hukum Islam (selanjutnya disebut KHI) akan tetapi dalam peraturan tersebut tidak ada peraturan khusus tentang adanya masa 'iddah bagi wanita hamil tersebut. Dan ketentuan dalam Kompilasi Hukum Islam sama sekali tidak menggugurkan setatus zina bagi sipelakunya, meskipun telah dilakukan perkawinan setelah terjadi kehamilan diluar nikah. Karena perbuatan yang sebelumnya tidak akan terhapuskan sekalipun akan dilakukanya pernikahan setelah itu dan hal ini akan semangkin rumit ketika dihadapkan pada suatu permasalahan di hubungkan dengan status anak yang akan dilahirkan. Dalam undang-undang nomor 1 tahun 1974 tentang perkawinan menyebutkan dalam pasalnya yang ke 42 berbunyi bahwa anak yang sah adalah anak yang di lahirkan dalam atau sebagai akibat perkawinan yang sah.

Hukum harusnya dapat memberikan perlindungan dan kepastian hukum yang adil terhadap status setiap anak yang dilahirkan dan hak-hak yang ada pada anak tersebut, termasuk terhadap 
anak yang dilahirkan di luar perkawinan yang sah menurut peraturan perundang-undangan yang ada terutama Kompilasi Hukum Islam.

Berdasarkan latar belakang di atas maka penulis tertarik untuk membahas permasalahan dengan judul kedudukan Anak yang Lahir di Luar Pernikahan di Tinjau dari Kompilasi Hukum Islam. Berdasarkan Uraian latar belakang diatas, maka yang menjadi pokok permasalahan dalam penelitian ini adalah akibat hukum anak yang di lahirkan wanita hamil yang di nikahkan menurut kompilasi hukum islam, status anak yang di lahirkan dari perkawinan wanita hamil di luar nikah di tinjau dari kompilasi hukum Islam.

\section{METODE PENELITIAN}

Menurut Marzuki bahwa penelitian hukum adalah suatu proses untuk menemukan prinsipprinsip hukum, doktrin-doktrin hukum, dan yang paling mendasar terkait aturan hukum, untuk menjadi solusi terhadap isu-isu hukum yang dihadapi (Marzuki, 2005, h. 35). Penulis dalam melakukan penulisan penelitian ini menggunakan metode penelitian hukum yuridis normatif dengan pendekatan secara undang-undang. Sumber bahan hukum yang digunakan menggunakan sumber data sekunder sebagai bahan utamanya yang terdiri dari bahan hukum primer berupa Kompilasi Hukum Islam dan perarturan yang berhubungan dengan masalah hukum yang di angkat, bahan hukum sekunder yang berupa bahan yang menjelaskan mengenai bahan hukum primer dan bahan hukum tersier berupa bahan penunjang yang membantu bahan primer dan bahan sekunder. Prosedur dalam pengumpulan data berupa bahan-bahan dari pustaka yang berhubungan dengan judul yang di angkat penulis. Selanjutnya dalam menganalisis bahan hukum mengunakan data kualitatif.

\section{PEMBAHASAN}

\section{Akibat Hukum Anak Yang di Lahirkan Wanita Hamil Yang di Nikahkan Menurut Kompilasi Hukum Islam}

Perkawinan yang sah merupakan perkawinan yang di lakukan oleh seorang pria dan seorang wanita tidak dalam keadaan paksa dan dilaksanakan sesuai dengan ketentuan Islam. Sesuai dengan ketentuan Islam sebelum adanya ikatan perkawinan maka, pria dan wanita dilarang melakukan suatu hubungan dan jika mereka telah melakukannya maka perbuatan tersebut dikatakan perbuatan zina. Jika hasil dari perbuatan mereka menyebabkan wanita tersebut mengandung anak dari pria yang melakukan hubungan dengannya, maka berdasarkan pandangan masyarakat anak tersebut di katakan sebagai anak zina sebab dari perbuatan kedua orang tuannya.

Kompilasi Hukum Islam menyatakan anak yang berasal dari persetubuhan di luar kawin yang berasal dari pria yang bukan suami sahnya menurut islam dan undang-undang tidak terhitung untuk mendapatkan warisan dan anak tersebut hanya mempunyai hubungan nasab dengan ibunya tetapi tidak dengan bapaknya, juga tidak berhak atas nafkah, dan pemeliharaan dari bapaknya. Status anak zina dalan Islam tersebut kembali ditegaskan dalam fatwa Majelis Ulama Indonesia pada tanggal 10 Maret 2012, yang antara lain menyatakan: (Fatwa MUI, 2012) 1. Anak dari hasil zina tidak memiliki hubungan nasab, nikah, waris, dan juga nafkah dengan ibunya dan keluarga ibunya.

2. Anak dari hasil zina hanya mempunyai hubungan nasab, waris, dan juga nafkah dengan ibunya dan keluarga ibunya. 
Islam menetapkan bahwa anak menempati garis kewarisan pertama dalam menerima warisan dari orang tuanya. Mengenai anak luar kawin sebagai anak yang tidak sah hanya mempunya hubungan hukum perdata dengan si ibu dan keluarga si ibunya dan tidak mempunyai hubungan hukum dengan ayah dan keluarga ayahnya. Oleh karena anak luar kawin, laki-laki maupun perempuan tidak di akui hubungan darah dengan ayahnya, maka anak tidak mewarisi harta ayahnya dan tidak pula dari seorang kerabat ayahnya sebagaimana ayahnya tidak mewarisinya lantaran tidak ada sebab pustaka mempusakai antara keduannya yaitu hubungan darah.

Menurut Wahbah Zuhaili menyebutkan bahwah ada beberapa cara untuk menentukan hubungan nasab seorang anak yaitu; perkawinan hanya mempunyai hubungan saling mewaris dengan ibunya dan keluarga ibunya (Al-Khalafi, Al-Wajiz, 2006, h. 799-800):

1. Hubungan perkawinan yang merupakan awal dari adanya hubungan nasab bagi anak dan keturunannya, sedangkan menurut Abdul Azim bin Badawi Al-Khalafi menyatakan hubungan darah pada umumnya harus di awali dengan suatu akad yang sah sesuai dengan Hukum Islam.,

2. Pengakuan garis nasab atau keturunan (itsbat nasab bil iqrar) berdasarkan pendapat dari Abdul Manan bahwa anak yang lahir di luar perkawinan tetap bisa diakui apabila tidak terpenuhinya secara nyata bahwa hubungan mereka tidak sah.

3. Mubaiyyinah (perbandingan) dengan melakukan pembuktian berdasarkan bukti yang sah bahwa seorang anak benar senasab dengan kedua orangtuanya dan mempunyai kemiripan orang tua dan anak tersebut.

Anak yang lahir di luar perkawinan hanya mempunyai hubungan nasab dengan ibunya saja, dan ahli waris orang yang pada saat meninggal dunia memiliki ikatan darah atau ikatan yang sah dengan pewaris, islam, dan tidak terhalang untuk mendapatkan warisan (Aulia, 2012, h. 52).

Beberapa akibat Hukum hak dan kewajiban anak dengan ibu yang melahirkan, dan ayah kandungnya yaitu: (Jurnal Pro Hukum, 2016)

1. Hubungan Nasab

Anak yang lahir di luar kawin hanya memiliki hubungan nasab dengan ibunya dan keluarga ibunya saja dan anak tersebut tidak dapat dinisabkan oleh ayah kandungnya walaupun secara nyata ayah kandungnya yang telah menghamili ibu yang melahirkan anak tersebut.

2. Nafkah

Karena anak di luar kawin hanya memiliki hubungan nasab dengan ibu dan keluarga ibunya, maka yang memberikan nafkah kepada anak tersebut yaitu ibu dan keluarga ibunya. Sedangkan jika anak yang sah ayah harus memberikan nafkah dan kehidupan yang layak dan baik contohnya pendidikan, kesehatan, dan nafkah sehari-hari kepada anak tersebut sesuai dengan penghasilannya jika ayah dan ibu masih dalam ikatan perkawinan yang sah sesuai ketentuan Islam. Apabila ayah dan ibu sudah berpisah maka ayah tetap harus di bebankan memberikan nafkah kepada anak-anaknya sesuai dengan kemampuannya.

3. Hak waris

Anak luar kawin hanya memiliki ikatan kewarisan dengan ibunya dan keluarga ibunya, maka secara hukum anak tersebut tidak memiliki ikatan saling mewaris dengan ayah kandungnya sesuai dengan ketentuan Kompilasi Hukum Islam. 


\section{Kedudukan Anak Luar Nikah Ditinjau Berdasarkan Kompilasi Hukum Islam (KHI)}

Kedudukan anak luar nikah diatur dalam Pasal 42, Pasal 43 Undang-Undang dan Pasal 283 KUHPerdata sebagai aturan hukum umum. Kedudukan anak dibagi menjadi tiga jenis yaitu :

1. Anak sah

2. Anak luar kawin yang diakui

3. Anak luar kawin yang tidak diakui

Namun ketentuan pembagian jenis kedudukan anak tersebut hanya diatur secara rinci pada KUHPerdata dan tidak diatur secara spesifik didalam Kompilasi Hukum Islam (KHI), melainkan hanya mengatur tentang apa yang dimaksud anak sah dan apa yang dimaksud dengan anak luar kawin (pada Pasal 186).

Pandangan Hukum Islam menetapkan bahwa kedudukan anak diketahui dari hubungan biologis antara ayah dan anak. Dikatakan bahwa anak tersebut merupakan anak kandung dari ayahnya jika anak tersebut dilahirkan dalam pernikahan yang legal dan resmi menurut agama Islam dan peraturan perundang-undangan terkait pernikahan. Sementara jika anak tersebut dilahirkan diluar pernikahan yang legal dan resmi maka anak tesebut hanya memiliki ikatan dengan ibunya bukan ayahnya, sehingga memungkinkan bahwa anak tersebut tidak akan menjadi ahli waris dari ayahnya, dan jika anak tersebut berjenis kelamin perempuan maka sang ayah tidak dapat menjadi wali nikahnya.

Namun berdasarkan putusan Mahkamah Konstitusi melalui pengujian undang-undang perkawinan terhadap Undang-Undang 1945, dalam inti putusannya menyatakan kedudukan anak diluar nikah tetap memiliki ikatan dengan ayahnya kandungnya jika dapat dibuktikan secara keilmuan dan surat pembuktiannya dikeluarkan oleh lembaga yang berwenang melakukan penelitian yang menyatakan bahwa anak tersebut memang memiliki DNA ayahnya, sehingga anak tersebut tetap dapat diakui dan dapat menjadi ahli waris dari ayahnya. Sesuai dengan pendapat para ahli fiqih yang menyatakan bahwa seorang anak memiliki ikatan dengan ayahnya jika anak tersebut hasil dari pernikahan legal dan resmi.

Wacana tentang kemungkinan penerapan Pengaduan Konstitusional di Indonesia tentunya tidak terlepas dari kewenangan Mahkamah Konstitusi sebagai salah satu pelaksana kekuasaan kehakiman. Pengaduan Konstitusional yang notabene berada dalam ranah pengujian konstitusional (constitutional review) jelas berada dalam area kewenangan Mahkamah Konstitusi (Kodiyat dan Sinaga, 2019, h.169).

Putusan tidak ada artinya apabila tidak dapat dilaksanakan. Oleh karena itu putusan hakim mempunyai kekuatan eksekutorial yaitu berkekuatan untuk dilaksanakan sesuai dengan apa yang ditetapkan dalam putusan itu secara paksa oleh alat-alat negara. Walaupun putusan pengadilan itu dapat dilakukan dan mempunyai kekuatan eksekutorial, tetapi banyak pihak yang masih merasa khawatir bahwa selama proses persidangan berlangsung tergugat akan menjual barang-barangnya atau dengan jalan lain mengalihkan hak atas barangnya, sehingga jika waktunya telah tiba putusan telah mempunyai kekuatan hukum yang tetap dan hendak dilaksanakan, barang yang menjadi objek persengketaan tidak dapat dieksekusi karena barang tersebut tidak berada ditangan tergugat lagi atau berada ditangan pihak ketiga yang tentunya sangat merugikan bagi pihak penggugat (Lubis, 2019, h. 43-44).

Jika telah terjadi kelahiran seorang anak hasil luar nikah maka solusi yang saat ini sering dilakukan masyarakat yaitu menikahkan perempuan tersebut dengan laki-laki yang menghamilinya ataupun bukan laki-laki yang menghamilinya. Tujuan dari pernikahan tersebut 
agar sang anak mempunyai kedudukan atau status yang dapat diterima dimasyarakat dan memiliki ikatan dengan ayah kandungnya.

Memang pada dasarnya tidak ada penyebutan anak sebagai anak haram atau anak zina karena dalam ajaran agama Islam tidak pernah menyebutkan seorang anak adalah anak zina meskipun anak tersebut lahir diluar nikah ataupun hasil hubungan gelap atau lainnya. Abu Hurairah mengatakan, Rasulullah SAW bersabda: "setiap anak dilahirkan dalam keadaan Fithrah. Kemudian kedua orang tuanyalah yang akan menjadikan anak itu menjadi Yahudi, Nashrani, atau Majusi” (HR. Ahmad, Ad-Darimi, an-Nasa I, Ibnu Jarir, Ibnu Hibban, AthThabrani, al-Hakim, Abu Na'im, dan Al-Baihaqi).

Ketidakamanan atau ketidakadilan yang ditimbulkan akibat dari kekerasan dalam rumah tangga itu sendiri dapat mencakup beberapa hal yaitu penderitaan atau penelantaran rumahtangga, kekerasan secara fisik, kekerasan seksual bahkan kekerasan secara psikis yang dapat menimbulkan hal-hal yang melanggar hukum dalam kehidupan rumahtangga.Tindak penelantaran rumahtangga, kekerasan fisik, kekerasan seksual dan kekerasan psikis dalam rumah tangga telah diatur dalam Undang-Undang Nomor 23 Tahun 2004 tentang Penghapusan Kekerasan Dalam Rumah Tangga (Asmadi, 2018, h. 40).

Berdasarkan pernyataan diatas, seorang anak yang lahir diluar pernikahan yang sah dan resmi berdasarkan unang-undang perkawinan bahkan yang termasuk karena hubungan gelap atau zinah, nikah sirih, nikah dibawa tangan ataupun bentuk pernikahan lain tidak akan menerima dosa akibat perbuatan orangtuanya. Mereka tetap dianggap suci sehingga kedudukan mereka harus lebih diperjelas oleh peraturan perundang-undangan agar tercapainya keadilan tehadap kedudukan si anak (Irfan, 2013, h. 125).

Pengertian dari anak sah yaitu anak yang dilahirkan sebagai akibat hukum terlaksananya suatu pernikahan yang legal dan resmi berdasarkan peraturan perundang-undangan yang berlaku (dalam hal ini undang-undang perkawinan), dan anak tersebut merupakan hasil dari pasangan suami istri seingga kemudian dilahirkan oleh istri tersebut (Anshary Mk, 2015, h. 62).

Kompilasi Hukum Islam memberikan kemungkinan adanya peluang terhadap anak yang dilahirkan jika seorang perempuan menikah dalam keadaan sedang mengandung anak tersebut dengan laki-laki yang menghamilinya dan kemudian setelah pernikahan anak tersebut lahir maka kedudukan anak tersebut legal sebagai anak dari ayah yang menikah dengan ibunya serta diakui oleh ayahnya bahwa anak tersebut merupakan anak kandungnya. Pernyataan tersebut sesuai dengan pendapat sahabat Umar bin Khattab melalui keputusannya menyatakan "beliau menasabkan anak-anak jahiliyah (pra islam) kepada mereka yang mau mengakui sebagai anaknya sesudah islam. (Berdasarkan riwayat Abdur Rozzaq dalam Al-Mushannaf). Selain itu, Sahabat Ibnu Abbas pernah ditanya terkait masalah seorang pria yang berzina dengan wanita lalu menikahinya dan menurut Ibnu Abbas menjawab "Mulanya melakukan zina, dan pada akhirnya menikah itu tidak apa-apa".

Menurut pendapat Imam Abu Hanifah secara tegas menyatakan bahwa kedudukan anak hasil zina akan menjadi sah atau legal serta dinasabkan kepada ayah biologisnya jika pria dan wanita yang melakukan hubungan di luar pernikahan yang legal secara agama Islam dan hukum melakukan pernikahan tersebut saat keadaan belum terjadinya kelahiran anak tersebut. Ibnu Qudamah dalam Al-Mughni mengambil pendapat Abu Hanifah yaitu "Seorang pria melakukan hubungan di luar penikahan bersama wanita dan kemudian wanita itu hamil, maka mereka di 
perbolehkan menikahi wanita itu saat sedang mengandung. dan status anak yaitu anak dari pasangan yang melakukan zina (Ibnu Qudamah dalam Al-Mughni)”.

\section{KESIMPULAN}

Anak yang lahir di luar perkawinan hanya memiliki hubungan nasab dengan ibunya dan keluarga ibunya yang dikatakan anak sah yaitu: anak yang lahir akibat perkawinan yang sah dan dari hasil pembuahan dari suami istri yang diluar rahim dan dilahirkan oleh istri tersebut.Jelas bahwa Kompilasi Hukum Islam membuka kemungkinan bagi tertampungnya anak yang lahir akibat perkawinan wanita hamil ke dalam anak sah sekalipun anak tersebut lahir beberapa hari setelah pernikahan dilaksanakan. KHI mengatur adanya bahwa anak yang berasal dari persetubuhan di luar kawin yang berasal dari pria yang bukan suami sahnya menurut islam dan undang-undang tidak terhitung untuk mendapatkan warisan dan anak tersebut hanya mempunyai hubungan nasab dengan ibunya tetapi tidak dengan bapaknya, juga tidak berhak atas nafkah, dan pemeliharaan dari bapaknya. Ditambahkan lagi dengan fatwa MUI, bahwa anak dari hasil zina hanya mempunyai hubungan nasab, waris, dan juga nafkah dengan ibunya dan keluarga ibunya.

\section{SARAN}

Seharusnya masyarakat sadar akibat hukum dari perzinahan, tidak hanya berdampak kepada si pembuat namun juga anak hasil perbuatannya yang tidak bersalah. Sehingga, harusnya berfikirlah sebelum melakukan.Semestinya di dalam Kompilasi Hukum islam lebih secara tegas lagi mengatur tentang katagori anak sah dan masalah hubungan nasab anak dengan ayahnya dan lebih tegas mengatur tentang anak yang lahir dari akibat ikatan yang legal berdasarkan batas minimal kehamilan 180 hari. 


\section{DAFTAR PUSTAKA}

Adz-Dzahabi, Kitab al-Kabar'ir Jakarta: Syirkah Dina Mutiara Berkah Utama.

Al-Khalafi, Abdul Azhim bin Badawi. (2006). Al-Wajiz, (terj: Ma'ruf Abdul Jalil). Jakarta: Pustaka As- Sunnah.

Anshary Mk. (2015). Hukum Perkawinan di Indonesia. Yogyakarta: Pustaka Pelajar.

Doi, Abdul Rahman I. (1996). Perkawinan Dalam Syari'at Islam. Jakarta: Rineka Cipta.

Ibrahim, Johny. (2006). Teori dan Metode Penelitian Hukum Normatif. Surabaya: Bayu Media Publishing.

Intruksi Presiden Republik Indonesia Nomor 1 Tahun 1991 Kompilasi Hukum Islam di Indonesia

Kodiyat MS, Benito Asdhie., Sinaga, Eza Ista Maulida. (2019). Kewenangan Mahkamah Konstitusi Dalam Perlindungan Hak Konstitusional Warga Negara Melalui Konstitusional Complaint. De Lega Lata Jurnal Ilmu Hukum Fakultas Hukum Umsu. 4 (2). 160-174. https://doi.org/10.30596/dll.v4i2.3174

Lubis, Mhd. Teguh Syuhada. (2019). Pelaksanaan Sita Jaminan Terhadap Objek Sengketa Yang Berada Di Tangan Pihak Ketiga Dalam Penanganan Perkara Perdata. De Lega Lata Jurnal Ilmu Hukum Fakultas Hukum Umsu. 4 (1). 42-53. https://doi.org/10.30596/dll.v4i1.3163

Lukman, Akbar Santoso. (2017). perlindungan hukum terhadap anak yang lahir Dari perkawinan perempuan hamil di luar nikah. Skripsi Sarjana Hukum: Universitas Lampung, Lampung.

Manan, Abdul. (2003). Aneka Masalah Hukum Material Dalam Praktek Peradilan Agama. Jakarta: Pustaka Bangsa.

Marzuki, Peter Mahmud. (2005). Penelitian Hukum. Jakarta: Kencana Prenada Media Group.

Quthb, Sayyid. (1987). Tafsir Fi Zilalil Qur'an. Beirut: Darus Syuruq. 